\title{
Legal Education of Children in The Family
}

\author{
Azizkhon Meliev \\ Kokand State Pedagogical Institute \\ Researcher of the Department of Pedagogy
}

\begin{abstract}
:
The article raises the first rudiments of legal culture on the formation of social, political and legal activity of the younger generation during the period of reforms and renewal under the motto "New Uzbekistan - a new worldview." The methods, means of legal education of children in the family are revealed.
\end{abstract}

Key words: New Uzbekistan, Constitution, family, child, parents, legal education, legal culture, legal activity.

\section{Introduction}

During the period of reforms and renewal under the motto "New Uzbekistan - a new worldview", the first shoots of legal culture to form the social, political and legal activity of the younger generation rose to the level of family politics in the new Uzbekistan. In the new Uzbekistan, the family is a pillar, a pillar of civil society. A person is not only born into a family, but is also brought up spiritually and morally. A family is a group of people that includes parents, their children and their immediate family. At the same time, the family is a social unit based on the natural, economic, legal and spiritual relations of people. The family is a natural unit of society, a social basis. The stronger the family, the stronger the society and the faster it develops. After all, the foundation of society - the material and social strengthening of the family - is very important. This means that family life is unique to all people. Thus, the family is the basic unit of society. And the child is the joy and future of the family. Mirza Ulugbek's views on the upbringing of a healthy generation in a family environment deserve special attention. He believes that in a family, parents, especially educated ones, should pay special attention to the development of their children into real people. One of the main responsibilities of a parent is to raise and educate a child.

\section{Main part}

The Constitution of the Republic of Uzbekistan says: "Parents are obliged to feed and educate their children until they reach adulthood." In the conditions of the new Uzbekistan, every child must live and be raised in a family, know his parents, take advantage of the care of his parents and live with his parents, be brought up by his parents, defend his interests, and develop. them in all respects and respect their human dignity. After all, Article 65 of the Family Code of the Republic of Uzbekistan reflects "the child's right to life and upbringing in the family" and contains the following content: The use of the child has the right to live with him, except when it is contrary to the interests of the child. A child has the right to be raised by his parents, to ensure his or her interests, to full development and to respect for his or her human dignity. In the absence of the child's parents or in the event of deprivation of parental rights and in other cases when the child is deprived of parental care, the child's right to be raised in a family is guaranteed by the guardianship and guardianship authority. "We see this in international law. For example, Article 7 of the Convention on the Rights of the Child reads:" He has the right to know his parents and enjoy their care. "Article 73 of the Family Code of the Republic of Uzbekistan" Rights and responsibilities of parents in raising children "reads:" Parents have the right and responsibility to educate their children Parents are responsible for 
the upbringing and development of their children. They need to take care of the health of their children, their physical, mental, spiritual and moral development. " This means that the more stable the relationship between the parents, the stronger the family and the better the children are brought up. Therefore, the importance of legal norms in building a humane, democratic rule of law in our country is high. In a family environment, a child must develop, along with other forms of legal education, that is, legal education of parents, the formation of legal literacy in their minds, the formation of legal culture in their behavior. We recommend studying and implementing the theory and practice of legal education in the family in the following 3 stages:

1. Preschool education, family for parents from birth to 7 years.

2. Primary school period, period from 7 to 10 years for family parents.

3. The period of high school, from 11 to 17-18 years old for family parents. The content of pedagogical and psychological literature describes the characteristics of the age, individual and psychological development of the child during the indicated periods. Taking into account the peculiarities of the age, individual and psychological development of children, we recommend that work in a family environment be carried out with the following difficulty:

- develop children's sensitivity to creative and negative life situations;

- develop general moral skills, take into account the views of adults and peers, if necessary, teach them to defend their views. Indeed, Article 17 of the Law of the Republic of Uzbekistan "On guarantees of the rights of the child" adopted by the Legislative Chamber on November 23, 2007 and approved by the Senate on December 1, 2007, states that "Guarantees of the right to freedom of religion" have the following meaning: "A child has the right to freedom of thought, speech, conscience and religion. The child's freedom of thought and expression may be limited in accordance with the law "formulate the first ideas about the state, its symbols, the Constitution and laws;

- fostering respect for family members, parents, brothers and sisters. There is a principle of spiritual and material support for those involved in family relationships and their mutual concern. Relationships between husband and wife, parents and children, grandparents and grandchildren, brothers and sisters, adoptive parents, etc. are primarily related to marriage, kinship or family ties. This is a personal relationship between people.

- to teach to distinguish between the possible and the impossible, good and bad, and to understand their meaning;

- to teach children to be polite, disciplined, caring;

- to give the first ideas about the Motherland, city, village, makhalla, people, customs, historical places where children were born and raised;

- Symbols of the Republic of Uzbekistan: acquaintance with the flag, coat of arms, anthem, national currency and education for their respect;

- to instill in children a sense of courage, courage and patriotism, instilling in them an interest in the military;

- On the restoration of independent Uzbekistan, freedom, liberty, the acquisition of the state language, national holidays;

- instill in children a sense of love and respect for the Uzbek people, its language, traditions, foster a sense of national pride;

- to teach the child to understand himself as a person; 
- To give an idea of our national holidays - Independence Day, Navruz, Eid al-Adha and others. Explain that it is our duty to preserve and study our spiritual heritage. Of course, work in this context is carried out in a family environment, forming first impressions in the minds of children.

Legal education is an ongoing process that needs to be taught from an early age. As mentioned above, children should know the rules of behavior first in the family, and then in preschool education, in order to get a basic understanding of morality and some legal norms, and in the future to expand and deepen this knowledge. In the process of organizing legal education in the family, we recommend that parents solve the following tasks:

- to provide children with basic information about the essence of legal norms, laws and social and legal relations and their significance in public life;

- to educate children in the need for legal knowledge, to achieve legal awareness;

- develop in children basic skills and competencies in organizing legal activities;

- ensuring that children have the first manifestations of positive legal qualities (legal imagination, legal perception, legal thinking, legal literacy, legal responsibility, legal activity, legal faith and legal capacity);

- Achievement of the formation of the legal culture of children (legal norms, correct assessment of the significance of laws in public life, respect for the Constitution and symbols of the state, as well as civil rights and obligations, organization of an uncompromising struggle against all forms of crime).

We have also developed methods and tools to ensure the effectiveness of this process in the theoretical and practical study of the process of organizing legal education in the family. Our recommendations in this regard are as follows:

- stories, explanations, conversations, interpretations, instructions, examples in the formation of legal consciousness in children;

- exercises, training, pedagogical requirements, educational situation, tasks for the formation of legal culture in children;

- it is advisable to use incentives, contests, reprimands, etc. in the process of making decisions on the legal quality in relation to children.

When implementing legal education in the family, it is advisable to use the following tools:

- genres of folklore, narration, rhetoric, proverbs, poems, fairy tales;

- from color books, magazines and newspapers (fiction and scientific literature);

- colorful pictures, photos;

- models, schemes, schemes;

- films, slides, slides, various exhibitions, currency;

- players

In a word, the family is the first step in the formation of a person's personality, the formation of skills and competencies in organizing legal activities on the basis of theoretical and legal knowledge acquired by a person, in determining the legal quality of a positive content and orientation towards the formation of legal culture, that is, relationships between people in family and in relation to society and the state. The family is the basic unit of society responsible for the growth of the population and the upbringing of the younger generation. Article 21 of the Family Code states that "the husband and wife jointly decide the issues of raising children and family life." 
So:

- the child's right to life and upbringing in a family with the help of a family;

- the right to visit parents and other relatives;

- the right to self-defense;

- the right to freedom of expression;

- the right to a name, patronymic and surname.

\section{Conclusion}

As a result, in the future, the problems of juvenile delinquency, unjustified divorces among young people, abandonment of children, an increase in the number of orphans, human trafficking, especially child trafficking, will be positively resolved. Of course, mutual consent of parents plays an important role in the legal upbringing of children and in solving certain issues of family life. Relationships between family members are governed by moral and legal norms.

\section{References}

1. Family Code of the Republic of Uzbekistan. National Database of Legislation, April 21, 2021, No. 21.03 / 683/0375)

2. Inomzhonova G.S. Problems of protection of parental and children's rights. - T.: Adolat, 2006. B.134.

3. Otahodzhaev F.M. The Constitution of the Republic of Uzbekistan and the family. -T.: TDYuI, 2002. - S.32.

4. Family law. Textbook / Authors. Prof. Under the general editorship of O.I. Okyulov. -T.: TSU Publishing House, 2016. 181 p.

5. Muminov A., Tillabaev M. Children's Rights. Electronic textbook. -T.: JIDU,

6. $2011 \mathrm{r}$.

7. Commentary on the Law of the Republic of Uzbekistan "On guarantees of the rights of the child" / A. Saidov et al. -T.: Vector-Press, 2009.

8. Right child: Textbook. / pod red. ОН. Saidova. -Т.: ТГЮИ, 2009. -251. 